\title{
Urinary Incontinence and Body Image in High-Risk and Usual Risk Pregnant Women
}

\author{
Giovana Secchi da Campo, ${ }^{1}$ Nandiny Paula Cavalli, ${ }^{2}$ \\ Melissa Medeiros Braz ${ }^{1}$
}

\begin{abstract}
Pregnancy can be defined as a period of approximately 40 weeks, in which physiological and mechanic adaptations occur, along with strong psychological modifications. Being a moment of vulnerability, it can be negatively influenced by factors such as urinary incontinence, high-risk pregnancy or even a negative body image. Thus, the aim of this study was to compare body image and the occurrence of urinary incontinence in high-risk and usual risk pregnant women. An observational study with a quantitative and cross-sectional approach was conducted to evaluate the occurrence of urinary incontinence and body image of pregnant women. The sample was divided into two groups: high-risk $(n=34)$ and usual risk $(n=31)$ pregnant women. For the data collection, an identification file was applied, collecting data such as obstetric history, followed by the International Consultation on Incontinence Questionnaire- Short Form (ICIQ-SF), and the Body Image Measurement Scale (BIMS). It was observed that both groups were dissatisfied with body image, and urinary incontinence occurrence was moderately above to what is found in literature. No relationship between urinary incontinence and body satisfaction was observed in either group. There was no relationship between urinary incontinence and body image. The pregnant women from both groups presented dissatisfaction regarding body image, and the occurrence of urinary incontinence was slightly higher than that observed in literature.
\end{abstract}

Keywords: Urinary Incontinence; body image; pregnancy.

\section{INCONTINÊNCIA URINÁRIA E AUTOIMAGEM CORPORAL EM GESTANTES DE ALTO RISCO E RISCO HABITUAL}

\section{RESUMO}

Introdução: A gestação pode ser definida como um período de aproximadamente 40 semanas, no qual ocorrem adaptações fisiológicas e mecânicas, juntamente com intensas transformações psíquicas. Sendo um momento de vulnerabilidade, pode ser influenciada negativamente por fatores como incontinência urinária, gestação de alto risco ou mesmo uma autoimagem corporal negativa. Objetivo: Comparar a autoimagem corporal e ocorrência de Incontinência Urinária (IU) em gestantes de alto risco e risco habitual. Métodos: Realizou-se um estudo observacional com abordagem quantitativa e caráter transversal, que avaliou a ocorrência de perda urinária e a imagem corporal de gestantes. A amostra foi dividida em dois grupos: gestantes de risco habitual e gestantes de alto risco. Para a coleta dos dados foram aplicados uma Ficha de Identificação, recolhendo dados como os antecedentes obstétricos, seguida do International Consultation on Incontinence Questionnaire - Short Form (ICIQ-SF) e da Escala de Medida em Imagem Corporal (Emic). Resultados: Observou-se que em ambos os grupos as gestantes demonstraram-se insatisfeitas com a imagem corporal, e a ocorrência de IU moderadamente acima do descrito na literatura (58,8\%). Não foi observada relação entre IU e autoimagem corporal em nenhum dos grupos. Conclusão: Não houve relação entre IU e autoimagem corporal. As gestantes de ambos os grupos apresentaram insatisfação em relação à imagem corporal, e a ocorrência de IU estava levemente superior àquela observada na literatura.

Keywords: Incontinência Urinária; autoimagem; gestação.

RECEBIDO EM: 2/10/2020

MODIFICAÇÕES SOLICITADAS EM: 26/6/2021

ACEITO EM: 20/7/2021

\footnotetext{
${ }^{1}$ Universidade Federal de Santa Maria. Santa Maria/RS, Brasil.

2 Autora correspondente. Universidade Federal de Santa Maria - Centro de Ciências da Saúde (CCS). Avenida Roraima, no 1000 - Camobi. Santa Maria/RS, Brasil. CEP 97105-900. http://lattes.cnpq.br/7543203067354782. https://orcid.org/0000-0001-8859-7996.nandiny@hotmail.com
} 


\section{INTRODUCTION}

Pregnancy can be characterized as the period of approximately 40 weeks, between conception and delivery, which includes physiological and mechanic adaptations, along with strong psychological modifications. During this moment of vulnerability, it is expected that the pregnant woman gets access to a prenatal care that encompasses, in addition to the biological scope, psychosocial aspects, since these have a direct influence on maternal and child health, as well as on the bond between mother and baby $y^{1,2,3}$.

Within the strong beauty standards associated to slimness in current culture, together with the wide exposure of stereotypical body images, many women have their body image negatively affected. Body image has a broad definition, being described as the representation of the body in our minds, and it is related to self-concept, always influenced by cultural aspects, in addition to other factors such as gender or age ${ }^{4,5,6}$. Being in a period of changes in body dimensions, psychic modifications and emotional instability, many pregnant women may find themselves in conflict with aesthetic values learned until then. Thus, these factors can unleash or exacerbate an inadequate body image, negatively affecting the pregnant woman's experience ${ }^{7,3}$.

Some other factors can influence the experience of pregnancy, such as the occurrence of urinary incontinence (UI) or a high-risk pregnancy. UI, defined by the International Continence Society as any complaint of involuntary loss of urine, can occur during pregnancy due to an alteration on muscular strength in the pelvic floor along with physiological changes of pregnancy, such as the uterus growth. Urine leakage can cause social discomfort, shame and embarrassment, even more so because many women do not search for medical assistance, thinking the problem is a symptom of pregnancy itself ${ }^{8,9,10}$. Hence, UI can have an impact on body image.

With respect to high-risk pregnancy, it is defined as the one in which the clinical course occurs in an unfavorable way, putting both fetal development and maternal health at risk ${ }^{11,12}$. High-risk pregnant women tend to remain more time at rest, therefore inactivity could impact body image, as well as UI. However, there is still a lack of studies that investigate the relationship between high-risk pregnancy and factors such as UI and body image.

Considering the above, this study aimed to compare body image and UI occurrence in high-risk and usual risk pregnant women. We hope to provide information that could contribute to a better assistance to pregnant women, with adequate prevention or treatment of $\mathrm{UI}$, as well as the support necessary to cope with the difficulties of adapting to this "new" body.

\section{METHODS}

This was an observational, descriptive, cross-sectional study with a quantitative approach, which included 65 pregnant women undergoing prenatal care at a healthcare network (a teaching-hospital and a primary health care unit). The participants were divided into two groups: usual risk (UR) and high-risk (HR) pregnant women. Data collection was carried out between January and April 2019.

Editora Unijuí - Revista Contexto \& Saúde - ISSN 2176-7114 - v. 21, n. 44, out./dez. 2021 
The sample consisted of primiparous and multiparous, usual or high-risk pregnant women, aged 18 or more, at the first, second or third trimester of pregnancy. The ones with diagnosis of neurologic or cognitive impairments that couId make them unable to answer the research tools were excluded. This study was previously approved by the institutional research ethics committee, number 2.544.970.

The participants were addressed and informed about the research and its procedures, and signed an informed consent. The high-risk pregnant women were addressed at the High-risk Pregnancy Ambulatory at the teaching-hospital, and the usual risk at a primary health care unit, while awaiting for their prenatal care appointments. All participants were properly instructed regarding the questionnaires that would be applied, and the risks and benefits of the study were clarified.

Three instruments were used for data collection, the first one being an identification file that included information such as age, marital status, education level and gestational age, based on the Brazilian Ministry of Health's Prenatal and Puerperium Technical Manual ${ }^{13}$ and Lemos ${ }^{14}$. Subsequently, the International Consultation on Incontinence Questionnaire Short Form (ICIQ-SF) was applied to evaluate the impact of UI on Quality of Life (QoL) and qualify the participants' urinary loss in a brief and simple manner. The ICIQ-SF consists of six questions, two of them regarding birth date and sex, and the other four referring to frequency, severity and impact of urinary loss on QoL. Overall score varies between zero and 21, zero meaning absence of $\mathrm{UI} ; 1$ to 3 indicating mild impact of $\mathrm{UI}$ in QoL; 4 to 6, moderate impact; 7 to 9, severe impact; and 10 or above, very severe impact ${ }^{10 .}$ Also, this questionnaire enabled the determination of the type of $\mathrm{UI}$.

Lastly, the Body Image Measure Scale (EMIC) was used to evaluate the women's body image. This scale was created by Souto ${ }^{15}$, aiming to facilitate the identification of body image disorders in nursery practice, and individualize interventions. Used previously in pregnant women ${ }^{6}$, EMIC consists of 23 affirmations, five of which having favorable meaning, and 18 unfavorable meaning. The items are disposed on a Likert scale. In the positive affirmations, the score is given as follows: 1 = never; 2 = rarely; 3 = sometimes; $4=$ frequently; $5=$ always. $\ln$ the negative items, the score is reversed. Overall score varies between 23 and 115 points. The instrument does not have a cut-off point, thus low scores indicate a negative body image, while high scores are related to a favorable body image ${ }^{6,15}$

Data normality was checked using the Shapiro-Wilk test. To compare parametric variables, two-tailed Student t test for independent samples was applied. Mann-Whitney test was used for comparison between nonparametric variables. The association between categorical variables was calculated by the $\mathrm{CHI}^{2}$ test. For the analysis of correlation between ordinal variables, the Spearman's test was used. All tests were applied with a significance level of $95 \%(p<0.05)$.

\section{RESULTS}

Sixty-five pregnant women, whose prenatal care monitoring was conducted at the healthcare network, participated on the study. Eligibility criteria are shown in Figure 1.

Editora Unijuí - Revista Contexto \& Saúde - ISSN 2176-7114 - v. 21, n. 44, out./dez. 2021 
Figure 1 - Eligibility criteria flowchart

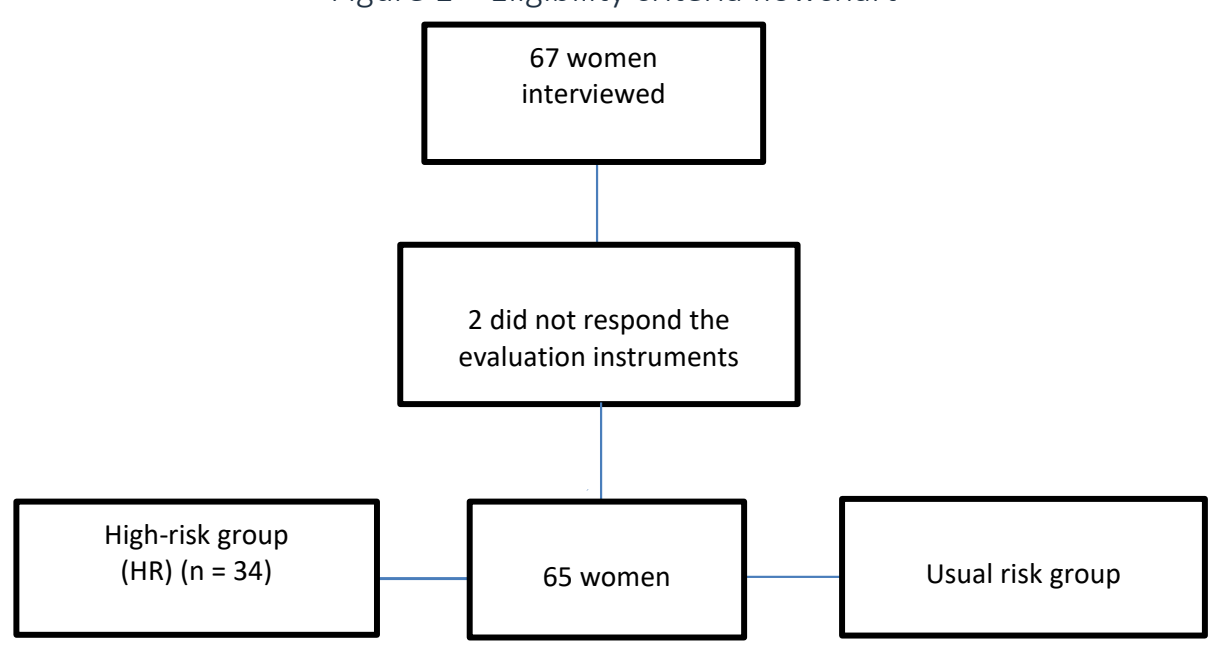

Source: Elaborated by the authors

Table 1 presents the socio-demographic characterization. The high-risk (HR) and usual risk (UR) groups were homogenous regarding age, obstetric history, skin color and marital status. The UR group reported more years of education when compared to HR ( $p=0.004)$.

Table 1 - Identification data from high-risk (HR, $n=34)$ and usual risk (UR, $n=31)$ pregnant women, presented as mean, standard deviation, absolute number ( $\mathrm{n}$ ) and percentage (\%)

\begin{tabular}{lccc}
\hline & HR group & UR group & P* \\
\hline Age & $31.12( \pm 7.05)$ & $28.50( \pm 5.20)$ & 0.091 \\
Gestational age (weeks) & $29.18( \pm 6.95)$ & $26.40( \pm 9.10)$ & 0.266 \\
Number of pregnancies & $2.59( \pm 1.52)$ & $1.8( \pm 0,8)$ & 0.124 \\
Number of deliveries & $1.24( \pm 1.33)$ & $0.6( \pm 0.7)$ & 0.188 \\
Number of abortions & $0.35( \pm 0.54)$ & $0.2( \pm 0.4)$ & 0.257 \\
Skin color & & & \\
White & $20(58.8 \%)$ & $26(83.9 \%)$ & 0.124 \\
$\quad$ Black & $8(23.5 \%)$ & $2(6.5 \%)$ & \\
$\quad$ Asian & $0(0 \%)$ & $0(0 \%)$ & \\
$\quad$ Mulatto & $5(14.7 \%)$ & $3(9.7 \%)$ & \\
$\quad$ Indigenous & $0(0 \%)$ & $0(0 \%)$ & \\
$\quad$ Non-informed & $1(2.9 \%)$ & $0(0 \%)$ & \\
Education & & & \\
$\quad$ Illiterate & $0(0 \%)$ & $0(0 \%)$ & 0.004 \\
$\quad$ Incomplete Elementary Education & $4(11.8 \%)$ & $2(6.5 \%)$ & \\
$\quad$ Complete Elementary Education & $3(8.8 \%)$ & $1(3.2 \%)$ & \\
$\quad$ Incomplete Secondary Education & $10(29.4 \%)$ & $1(3.2 \%)$ & \\
Complete Secondary Education & $15(44.1 \%)$ & $14(45.2 \%)$ & \\
Incomplete Higher Education & $0(0 \%)$ & $4(12.9 \%)$ & \\
Complete Higher Education & $2(5.9 \%)$ & $9(29.0 \%)$ & \\
Marital Status & & & \\
With Partner & $26(76.5 \%)$ & $25(80.6 \%)$ & 0.226 \\
Without Partner & $8(23.5 \%)$ & $6(19.4 \%)$ & \\
\hline
\end{tabular}

*P values for two-tailed Student t test (parametric variables) and Mann-Whitney test (nonparametric variables). Source: Elaborated by the authors. 
The number of incontinent pregnant women on the study was 41 (58.8\%), with 20 (58.8\%) in the HR group and 21 (67.8\%) in the UR group, without statistical difference between groups $(p=0.385)$. The characteristics of urinary losses are shown in Table 2.

Table 2 - Characteristics of high-risk (HR, $n=34)$ and usual risk (UR, $n=31)$ pregnant women's urinary losses, presented as absolute number $(n)$, percentage and $p$ value

\begin{tabular}{lccc}
\hline & HR & UR & \\
\hline Amount of urinary loss & $\mathrm{n}(\%)$ & $\mathrm{n}(\%)$ & $\mathrm{P}^{*}$ \\
None & $14(41.2)$ & $10(32.3)$ & 0.148 \\
Small & $13(38.2)$ & $18(58.1)$ & \\
Moderate & $03(08.8)$ & $13(9.7)$ & \\
Severe & $04(11.8)$ & $0(0)$ & \\
\hline Frequency of urinary loss & & & \\
Never & $14(41.2)$ & $10(32.3)$ & 0.457 \\
Once a week or less & $08(23.5)$ & $09(29.0)$ & \\
Two or three times a week & $05(14.7)$ & $02(06.5)$ & \\
Once a day & $01(02.9)$ & $03(09.7)$ & \\
Multiple times a day & $05(14.7)$ & $03(09.7)$ & \\
All the time & $01(02.9)$ & $04(12.9)$ & \\
Impact of urinary loss & & & \\
Continent & $14(41.2)$ & $10(32.3)$ & 0.385 \\
Mild & $06(17.6)$ & $02(06.5)$ & \\
Moderate & $04(11.8)$ & $07(22.6)$ & \\
Severe & $05(14.7)$ & $04(12.9)$ & \\
Very severe & $05(14.7)$ & $08(25.8)$ & \\
\hline Ul type & & & \\
Continent & $14(41.2)$ & $10(32.3)$ & 0.428 \\
SUl & $09(26.5)$ & $12(38.7)$ & \\
UUl & $02(05.9)$ & $04(12.9)$ & \\
MUl & $09(26.5)$ & $05(16.1)$ & \\
\hline
\end{tabular}

$\mathrm{UI}$ : urinary incontinence. SUI: stress urinary incontinence. UUI: urge urinary incontinence. MUI: mixed urinary incontinence.

*P values for two-tailed Student $\mathrm{t}$ test (parametric variables) and Mann-Whitney test (nonparametric variables). Source: Elaborated by the authors.

Table 3 shows the comparison between high-risk $(H R, n=34)$ and usual risk $(U R, n=31)$ pregnant women's body image. There were no statistically significant differences between the groups.

Table 3 - High-risk (HR, n=34) and usual risk (UR, n=31) pregnant women's body image, presented as EMIC scores in mean, standard deviation and $p$ value.

\begin{tabular}{lccc}
\hline Domains & HR & UR & $P^{*}$ \\
\hline Total score & $89.71( \pm 19.53)$ & $92.7( \pm 17.5)$ & 0.519 \\
BR & $27.68( \pm 6.13)$ & $28.20( \pm 5.40)$ & 0.906 \\
BI & $41.91( \pm 10.44)$ & $43.00( \pm 9.70)$ & 0.655 \\
BP & $20.12( \pm 4.92)$ & $21.50( \pm 3.50)$ & 0.403 \\
\hline
\end{tabular}

BR: body reality. BI: body ideal. BP: body presentation.

*P values for two-tailed Student $t$ test (parametric variables) and Mann-Whitney test (nonparametric variables).

Source: Elaborated by the authors. 
It was observed that both groups presented body dissatisfaction ( $p=$ 0.290) according to the equilibrium analyses between the three components of body image (BR\%, BI\%, BP\%) $)^{16}$. These data are shown in Table 4.

Table 4 - High-risk (HR, n=34) and usual risk (UR, n=31) pregnant women's body satisfaction, presented as absolute number, percentage and $p$ value.

\begin{tabular}{lccc}
\hline & HR & UR & $\mathrm{P}^{*}$ \\
\hline Body Satisfaction & $\mathrm{n}=34$ & $\mathrm{n}=31$ & \\
Satisfied & $08(23.53 \%)$ & $11(35.48 \%)$ & 0.290 \\
Dissatisfied & $26(76.47 \%)$ & $20(64.52 \%)$ & \\
\hline
\end{tabular}

*P values for two-tailed Student $t$ test (parametric variables) and Mann-Whitney test (nonparametric variables). Source: Elaborated by the authors.

There was no relationship between $\mathrm{UI}$ and body satisfaction. This was observed considering all the pregnant women $(p=0.723)$, usual risk group ( $p=$ $0.723)$, and high-risk group $(p=0.923)$.

\section{DISCUSSION}

The present study evaluated high-risk and usual risk pregnant women's body image, aiming to relate it to the occurrence of urinary incontinence. The sample found was characterized, on average, by adult, white women at the second trimester of pregnancy, and thus with a small number of prenatal care visits until the moment of the study. Mean age was 29.8 years, similar to the study by Meireles ${ }^{7}$, which found a mean age of 29.3 years, indicating a preference for a more delayed pregnancy.

In terms of educational level, the UR group presented more years of education (complete or incomplete higher education), while HR group had complete or incomplete secondary education, which could suggest schooling as a protective factor for pregnant women, or perhaps because a higher education stage could be related to a higher income and, consequently, the seek for medical care at a private network. No other studies were found regarding the relationship between education and high-risk pregnancy.

With respect to body image, both groups were dissatisfied, with no significant difference between them. Overall score was 91.2 points, and UR and HR groups' scores were, respectively, 89.7 and 92.7 points, within the variation of 23 to 115 . The obtained scores are similar to what was observed in the study by Meireles ${ }^{6}$, in which 55 pregnant women between first and third gestational trimester were assessed, and which presented the average of 85.7 points using EMIC.

A total of $58.8 \%$ of the pregnant women presented UI, similar to the study by Farias ${ }^{16}$, in which $53.8 \%$ of the pregnant women interviewed were incontinent. These numbers are slightly higher than the estimate that $50 \%$ of Brazilian women present IU, especially during the pregnancy-puerperium cycle ${ }^{9,17}$. There was no significant difference in the occurrence of UI between the groups, which 
can be due to the fact that most of the women on HR group were not at rest, so that a greater functional decrease in the pelvic floor muscles would not occur.

At the HR group, the predominant type of UI was stress, corroborating previous studies by Duarte ${ }^{18}$ and Rocha ${ }^{19}$. At the UR group, the prevalence was the same for SUI and MUI. The occurrence of UI during pregnancy can be explained by the anatomic changes characteristic at this period, such as the increased intra-abdominal pressure due to the physiological weight gain and fetal growth, as well as the hormonal alterations, such as the rise in progesterone levels, which can be related to bladder and urethra smooth muscle tone decrease ${ }^{19,20,21 .}$

The presence of UI can bring along negative psychosocial effects regarding self-esteem, body image, anxiety and depression. ${ }^{22}$ A study with pregnant women at the third trimester found a prevalence of 59.9\% of UI among the 242 participants, and an association between the presence of UI symptoms and depressive episodes was observed. ${ }^{23}$ With respect to women at the first year after delivery, it was demonstrated that $\mathrm{UI}$ affects the psychological well-being in this group. ${ }^{24}$ That way, UI could be related to a negative body image during pregnancy, adding to the other factors mentioned previously.

The initial hypothesis brought by this study presupposes that high-risk pregnant women, tending to remain more time at rest, may have an impaired body image due to the inactivity period when compared to usual risk pregnant women. This resting period can also influence the function of the pelvic floor muscles, facilitating the occurrence of UI. Hence, UI could have a relationship, even if indirectly, with body image. However, no relationship was found between body satisfaction and occurrence of UI.

The majority of the women on HR group were not in absolute rest, performing their daily life activities, even if in an adapted manner. Thus, the occurrence of high-risk pregnancy may not have been able to influence body image, justifying the result of the study. The body dissatisfaction in both groups can be explained by many factors reported in the literature. Weight gain along with a higher BMI during pregnancy appears as one of the main factors of dissatisfaction, with a greater discrepancy between real and idealized body. Furthermore, many women fear the loss of their pre-pregnancy body, although understanding that the changes in their bodies are physiological and necessary 25,26,27.

Body image is still neglected by health professionals when it comes to pregnant patient ${ }^{25}$. However, a good communication with this population can allow a better understanding about which changes to expect throughout pregnancy, as well as the adjustment of one's ideals of body image and adjustment to changes ${ }^{26 .}$

A few limitations can be identified in the present study, such as convenience sampling, sample size, and variables that were not assessed, in particular the resting period. We highlight the importance of more national studies on the subject, with larger sample sizes, aiming to better understand how Brazilian pregnant women deal with their body image. 


\section{CONCLUSION}

No relationship between $\mathrm{UI}$ and body image was observed in the groups studied. In both groups the pregnant women were dissatisfied with their body image, which suggests that the health team should be prepared to identify these alterations and provide better assistance, and the occurrence of UI was slightly higher than the rate reported in the literature. It is therefore suggested that future studies compare the trimesters of pregnancy and analyze gestational BMI and the effects of weight gain on the variables, relating it to factors such as socioeconomic condition and anxiety. It is also suggested more national studies on the subject, for a better understanding about how Brazilian pregnant women deal with body image, and how physical therapy can assist them during that period.

\section{DISCLOSURE STATEMENT}

The authors declare no conflicts of interest.

\section{REFERENCES}

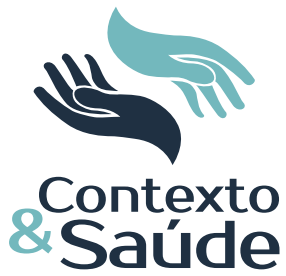

${ }^{1}$ Khalesi ZB, Bokaie M, Attari SM. Effect of pregnancy on sexual function of couples. African Health Sciences. 2018;18(2):227-234.

2 Silveira RAM, Milani RG, Velho APM, Marques AG. Percepção de gestantes sobre o autocuidado e o cuidado materno. Revista da Rede de Enfermagem do Nordeste. 2016;17(6):758-765.

${ }^{3}$ Vianna M, Vilhena JD. Para além dos nove meses: uma reflexão sobre os transtornos alimentares na gestação e puerpério. Trivium: Estudos Interdisciplinares. 2016;8(1):96109.

${ }^{4}$ Santos AJND, Souza GS de, Galvão PVM. Depressão em adolescentes e sua relação com a imagem corporal. Multidisciplinary Reviews. 2019;2:1-3.

${ }^{5}$ Meireles JFF, Neves CM, Carvalho PHB, Ferreira MEC. Imagem corporal de gestantes: um estudo longitudinal. Jornal Brasileiro de Psiquiatria. 2016;65(3):223-230.

${ }^{6}$ Meireles JFF, Neves CM, Carvalho PHB, Ferreira MEC. Satisfação corporal, idade gestacional e estado nutricional em gestantes. ABCS Health Sciences. 2016;41(1):23-28.

7 Meireles JFF, Neves CM, Carvalho PHB, Ferreira MEC. Imagem corporal, atitudes alimentares, sintomas depressivos, autoestima e ansiedade em gestantes de juiz de fora, Minas Gerais, Brasil. Revista Ciência \& Saúde Coletiva. 2017;22(2):437-445.

8 Pinheiro AV do N, Oliveira JA, Matos NJG, Moussa L, Mendes MRP. Estudo da prevalência de sintomas da incontinência urinária de esforço durante o período gestacional em primigestas: uma revisão de literatura. Revista Pesquisa e Ação. 2017;3 (2):93-106.

${ }^{9}$ Ribas LL, Oliveira EA, Cirqueira RP, Ferreira JB. Impacto da incontinência urinária na qualidade de vida das gestantes. Id On Line, 2019;13(43):431-439.

10 Tamanini J, Dambros M, D’Ancona CAL, Palma PCR, Netto Jr, NR. Validação para o português do "International Consultation on Incontinence Questionnaire - Short Form" (ICIQ-SF). Revista Saúde Pública. 2004;38(3):438-444.

${ }^{11}$ Costa LD, Cura CC, Perondi AR, França VF, Bortoloti DS. Perfil epidemiológico de gestantes de alto risco. Cogitare Enfermagem. 2016;21(2):1-8.

12 Oliveira ACMD, Graciliano NG. Síndrome hipertensiva da gravidez e diabetes mellitus gestacional em uma maternidade pública de uma capital do nordeste brasileiro, 2013: prevalência e fatores associados. Revista Epidemiologia e Serviços de Saúde. 2015;24(3):441-451.

Editora Unijuí - Revista Contexto \& Saúde - ISSN 2176-7114 - v. 21, n. 44, out./dez. 2021 
${ }^{13}$ Brasil. Ministério da Saúde. Secretaria de Atenção à Saúde. Departamento de Ações Programáticas Estratégicas. Pré-natal e Puerpério: atenção qualificada e humanizada: manual técnico. Brasília: Ministério da Saúde; 2006. 162p.

${ }^{14}$ Lemos A. Fisioterapia obstétrica baseada em evidências. 1. ed. Rio de Janeiro: Medbook; 2014

${ }^{15}$ Souto CMRM, Garcia TR. Construction and validation of a body image rating scale: a prelirninaw studu. International journal of nursing terminologies and classification. 2002;13(4):117-126.

${ }^{16}$ Farias TC, Morais KCS, Cirqueira RP, Albuquerque LS, Ferreira JB. Incontinência urinária e disfunção sexual em gestantes. id on-line Revista de Psicologia. 2017;11(38):237-248.

${ }^{17}$ Epaminondas LCS., Negrão LN, Costa SAS, Macêdo RC. As repercussões da incontinência urinária na qualidade de vida em gestantes: uma revisão sistemática. Revista Pesquisa em Fisioterapia. 2019;9(1):120-128.

${ }^{18}$ Araújo APS, Duarte NLS, Benavides G, Oliveira DVO, Benedeti M. Prevalência de incontinência urinária em mulheres praticantes de exercícios físicos. Perspectivas on-line: Biológicas e da Saúde. 2015;16(5):20-26.

${ }^{19}$ Rocha J, Brandão P, Melo A, Torres S, Mota L, Costa F. Avaliação da incontinência urinária na gravidez e no pós-parto: estudo observacional. Acta Médica Portuguesa, Penafiel, Portugal. 2017;30(7-8):568-572.

${ }^{20}$ Sangsawang B, Sangsawang N. Stress urinary incontinence in pregnant women: a review of prevalence, pathophysiology, and treatment. International Urogynecology Journal, Bangkok. 2013;24:901-912.

${ }^{21}$ Balik GL, Guven ESG, Tekin YB, Senturk S, Kagitci M, Ustuner I, et al. Lower Urinary Tract Symptoms and Urinary Incontinence During Pregnancy. Lower Urinary Tract Symptoms. 2014;8(2):120-124.

22 Saiki L, Meize-Grochowski R. Urinary Incontinence and Psychosocial Factors Associated with Intimate Relationship Satisfaction Among Midlife Women. Journal of Obstetric, Gynecologic \& Neonatal Nursing. 2017;46(4):555-566.

23 Sacomori C, Bõer L, Sperandio FF, Cardoso FL. Prevalência e variáveis associadas à incontinência urinária no terceiro trimestre gestacional. Revista Brasileira de Saúde Materno Infantil. 2013;13(3):215-221.

24 Åhlund S, Rothstein E, Radestad I, Zwedberg S, Lindgren H. Urinary incontinence after uncomplicated spontaneous vaginal birth in primiparous women during the first year after birth. International Urogynecology Journal. 2019;1-8.

25 Roomruangwong C, Kanchanatawan B, Sirivishayakul S, Maes M. High incidence of body image dissatisfaction in pregnancy and the postnatal period: associations with depression, anxiety, body mass index and weight gain during pregnancy. Sexual \& reproductive healthcare. 2017;13:103-109.

${ }^{26}$ Watson B, Broadbent J, Skouteris H, Fuller-Tyszkiewicz M. A qualitative exploration of body image experiences of women progressing through pregnancy. Women and Birth. 2015;29(1):72-79.

${ }^{27}$ Tsuchiya S, Yasui M, Ohashi K. Assessing body dissatisfaction in japanese women during the second trimester of pregnancy using a new figure rating scale. Nursing \& Health Sciences. 2019;11:1-8. 